\title{
Requirement of fattening pigs for gross and digestible lysine in feeds with easily and poorly digestible protein
}

\author{
G. J. Borggreve and W. A. G. Veen \\ CLO-Institute for Animal Nutrition 'De Schothorst', Lelystad, Netherlands
}

Received 9 June 1983; accepted 5 December 1983

Key-words: pigs, feeding trial, digestibility trial, gross lysine requirement, digestible lysine requirement

\section{Summary}

In a feeding trial involving 96 fattening barrows and gilts and based on a $2 \times 3$ experimental design, feeds containing poorly digestible protein sources were compared with feeds containing easily digestible protein sources, at lysine levels of 6.9 , 7.5 and $8.1 \mathrm{~g} / \mathrm{kg}$. In the liveweight range from 30 to $70 \mathrm{~kg}$ daily rate of gain on both types of ration was higher with higher lysine level in the feed. Over the entire growth range from 30 to $110 \mathrm{~kg}$, the rate of gain was proportional to lysine content only for the ration with poorly digestible protein.

In this experiment the requirement for gross lysine appeared to be 7.0 to $7.5 \mathrm{~g} / \mathrm{kg}$ for the feed with easily digestible protein and at least $7.9 \mathrm{~g} / \mathrm{kg}$ for the feed with poorly digestible protein.

In a digestibility trial with pigs weighing approximately $30 \mathrm{~kg}$ the apparent digestibility of the feeds with the lowest and highest lysine levels was determined. The digestibility coefficient of the crude protein was 7 to 12 units lower than figures given in de CVB table (Central Bureau on Livestock Feeding in the Netherlands). The digestibility coefficients for lysine were only marginally lower than for crude protein. On the basis of the digestibility coefficients determined for lysine, it was possible to calculate the requirement for digestible lysine for the pigs used in the feeding trial. Results showed a level of 5.3 to $5.7 \mathrm{~g} / \mathrm{kg}$ for the ration containing easily digestible protein, and at least $5.6 \mathrm{~g} / \mathrm{kg}$ for the feed with poorly digestible protein. We concluded that pig feeds should be composed on the basis of digestible lysine content rather than on gross lysine content.

\section{Introduction}

The protein requirement of an animal is primarily a requirement for essential amino acids. As the ingredients used in mixed feeds contain proteins which vary in digestibility and in amino acid pattern, it is to be expected that they do not have the same value for the protein synthesis of an animal. 
Considering the fact that the feedstuffs for pigs vary significantly in protein digestibility, we may assume that this also applies to the digestibility of the amino acids. It is noteworthy, then, that up to now in the Netherlands in pig feeding the requirement for essential amino acids is expressed in terms of the gross amino acid content, without reference to the digestibility of the amino acids.

The fact that digestible amino acids are not yet used in formulating pig feeds is due to the lack of adequate information on the amino acid digestibility of the various feedstuffs. The digestibility of amino acids cannot simply be deduced from that of the protein, as various experiments have shown that the apparent faecal digestibility of individual amino acids differs from the apparent faecal digestibility of protein, especially in less digestible feedstuffs (Lenis, 1980). For poorly digestible ingredients the digestibility of the essential amino acid lysine was significantly lower than that of the crude protein (Slump et al., 1977; Lenis, 1980).

Therefore we decided that it was important to determine the extent of the difference which can result from formulating pig feeds with easily or poorly digestible proteins on the basis of gross amino acid content, and to establish whether this situation can be improved by calculating with data of digestible amino acid content. For this purpose we carried out a pig-feeding trial in which two types of feed, composed of ingredients which sharply differed in protein digestibility, were tested to determine which level of gross lysine produced the best growth results.

\section{Materials and methods}

\section{Feeding trial}

The trial was set up according to the experimental design shown in Table 1. The trial was carried out with 96 individually housed pigs of a commercial cross-breed commonly used in the Netherlands. The 40 barrows and 56 gilts were given from the liveweight of ca. 22 to ca. $30 \mathrm{~kg}$ the same starter feed. They were then divided into 6 groups and the experimental feeds were administered according to a feeding plan based on body weight. The starter feed and the experimental feeds were all pelleted, and given as dry feed. The pigs had free access to water.

The easily digestible protein sources were soya bean meal, barley and wheat, the poorly digestible protein sources were wheat middlings and horse beans. Different levels of lysine were achieved by exchanging barley for soya bean oil meal. The

Table 1. Experimental design.

\begin{tabular}{lll}
\hline Treatment & Feed & Lysine in feed $\left(\mathrm{g} / \mathrm{kg}\right.$ at $\left.\mathrm{EW}^{*}=1.03\right)$ \\
$\mathrm{A}$ & easily digestible protein & 6.9 \\
$\mathrm{~B}$ & easily digestible protein & 7.5 \\
$\mathrm{C}$ & easily digestible protein & 8.1 \\
$\mathrm{D}$ & poorly digestible protein & 6.9 \\
$\mathrm{E}$ & poorly digestible protein & 7.5 \\
$\mathrm{~F}$ & poorly digestible protein & 8.1 \\
\hline
\end{tabular}

${ }^{*} \mathrm{EW}=$ net energy $(\mathrm{kJ} / \mathrm{kg})$ according to Rostock formula, divided by $8800 \mathrm{~kJ} / \mathrm{kg}$. 
Table 2. Composition of the experimental feeds. ${ }^{1}$

$\mathrm{A}^{2}(\%) \quad \mathrm{C}^{2}(\%) \quad \mathrm{D}(\%) \quad \mathrm{F}(\%)$

Wheat middlings ( $\mathrm{cf}=8.2 \%$ )

$\begin{array}{lccc}- & - & 30 & 30 \\ - & - & 20 & 20 \\ - & - & 20 & 20 \\ 20 & 20 & - & - \\ 31.5 & 31.5 & - & - \\ 17 & 21.5 & 3.5 & 8 \\ 18.8 & 14.2 & 18.8 & 14.2 \\ 2.5 & 2.5 & 2.5 & 2.5 \\ 2 & 2 & 2 & 2 \\ 0.5 & 0.5 & 0.5 & 0.5 \\ 0.4 & 0.6 & 0.4 & 0.6 \\ 1.4 & 1.3 & 0.8 & 0.7 \\ 0.6 & 0.6 & 1.2 & 1.2 \\ 0.3 & 0.3 & 0.3 & 0.3\end{array}$

Horse beans $(\mathrm{cp}=24.4 \%)$

Maize starch

Wheat

Tapioca meal $(\operatorname{starch}=65 \%)$

Soya bean oil meal $(\mathrm{cp}=48 \%)$

Barley

Molasses (-cane)

Rendered fat

Trace elements/vitamin concentrate

Methionine premix $(10 \%)$

$\mathrm{CaHPO}_{4} \cdot 2 \mathrm{H}_{2} \mathrm{O}$

Limestone

Sodium chloride

95.0

95.0

100.0

100.0

Calculated $(\mathrm{g} / \mathrm{kg})$

$\begin{array}{lcccc}\text { cp } & 142 & 159 & 138 & 154 \\ \text { dcp } & 122 & 139 & 114 & 130 \\ \text { Lysine } & 7.3 & 8.5 & 6.9 & 8.1 \\ \text { Methionine + cystine } & 4.9 & 5.6 & 4.6 & 5.2 \\ \text { Starch } & 438 & 414 & 408 & 385 \\ \text { EW } & 1.08 & 1.08 & 1.03 & 1.03\end{array}$

${ }^{1} \mathrm{cf}=$ crude fibre; $\mathrm{cp}=$ crude protein; $\mathrm{EW}=$ net energy $(\mathrm{kJ} / \mathrm{kg})$ according to Rostock formula, divided by $8800 \mathrm{~kJ} / \mathrm{kg}$.

${ }^{2}$ Since feeds $A$ and $C$ had a feeding value $5 \%$ higher than that of feeds $D$ and $F$, they were administered at a $5 \%$ lower level.

composition of feeds A, C, D and F is given in Table 2. Feed B was obtained by combining equal quantities of $\mathrm{A}$ and $\mathrm{C}$, and feed $\mathrm{E}$ by mixing equal quantities of $\mathrm{D}$ and $\mathrm{F}$.

Because the calculated feeding value of feeds $\mathrm{A}, \mathrm{B}$ and $\mathrm{C}$ was $5 \%$ higher than that of feeds D, E and $\mathrm{F}$ respectively, the feeds $\mathrm{A}, \mathrm{B}$ and $\mathrm{C}$ were administered at a level of $95 \%$ of feeds D, E and F. Four batches of each feed were prepared. All feed batches were analysed for crude protein content and starch, and feeds A, C, D and $\mathrm{F}$ were also analysed for lysine, methionine and cystine. The starch levels agreed quite closely with the calculated levels. The same was true for the crude protein content of feeds A, B and C. The crude protein contents of feeds D, E and F were lower than calculated, on an average 9,7 and $6 \mathrm{~g} / \mathrm{kg}$ respectively. The calculated and determined amino acid levels are given in Table 3.

\section{Digestibility trial}

For this trial we used 6 special cages which made it possible to collect the faeces and urine of the gilts separately. Only feeds $A$ and $C$ and $D$ and $F$ were used for this tri- 
Table 3. Protein and amino acid contents of the experimental feeds.

$\begin{array}{llcc} & & \text { Calculated }(\mathrm{g} / \mathrm{kg}) & \text { Determined }(n=4)(\mathrm{g} / \mathrm{kg}) \\ \text { A } & 142 & 142 \\ & \text { crude protein } & 7.3 & 7.3 \\ & \text { lysine } & 5.3 \\ \text { methionine + cystine } & 4.9 & 156 \\ \mathrm{C} & 159 & 8.7 \\ & \text { crude protein } & 8.5 & 5.9 \\ & \text { lysine } & 5.6 & 129 \\ & \text { methionine }+ \text { cystine } & 6.6 \\ \text { D } & \text { crude protein } & 138 & 4.6 \\ & \text { lysine } & 6.9 & 148 \\ & \text { methionine }+ \text { cystine } & 4.6 & 7.9 \\ & & 154 & 5.4 \\ \text { F } & \text { crude protein } & 8.1 & \end{array}$

al. The quantities required were composed of more or less equal quantities of meal, which were set aside each time a new batch was made up for the feeding trial. The various batches were thoroughly mixed and samples were taken which were tested in the laboratory for hydrochloric acid insoluble ash. In some cases Celite (a diatomaceous earth) was added, so that the total level of hydrochloric acid insoluble ash in all 4 feeds was approximately $1.3 \%$. Hydrochloric acid insoluble ash was used as a marker for determining digestibility coefficients. After mixing the feeds were pelleted.

The pigs were transferred to the cages on Thursday. At this point they weighed on average $26 \mathrm{~kg}$. The feed was administered twice a day in two equal portions. During the first few days the quantity of feed was gradually increased until it reached $4 \%$ of body weight. From Monday on, the quantity of feed was kept at the same level. The faeces were collected as completely as possible from Tuesday morning up to and including the following Monday morning, after which the trial was terminated. The pigs then weighed, on an average, $32 \mathrm{~kg}$.

The faeces were collected daily and kept in covered buckets at a temperature of $5{ }^{\circ} \mathrm{C}$. At the end of the collection period the faeces samples taken from each animal were carefully homogenized and a bit of water was added. Then samples of the wet material were taken, and the dry matter content, crude protein (Kjeldahl), crude fat (Berntrop method with hexane extraction), crude fibre, ash and hydrochloric acid insoluble ash were determined immediately. A portion of the faeces from two pigs of each treatment was freeze-dried and afterwards analysed for lysine content. The digestibility coefficients $(d)$ of crude protein $(\mathrm{cp})$ etc. were calculated on the basis of the following formula:

$d_{\mathrm{cp}}=100((\mathrm{cp}$ content of feed $-(\mathrm{HCl}$-insoluble ash content of feed/HCl-insoluble ash content of faeces) $\times$ cp content of faeces) $/$ cp content of feed). 
For each treatment average protein digestibility coefficient with standard deviation was calculated.

\section{Results}

\section{Feeding trial}

Average daily liveweight gain and feed conversion are shown in Table 4. As the $\mathrm{EW}^{1}$ of the feeds differed, feed conversion is calculated as consumed $\mathrm{EW}$ per $\mathrm{kg}$ liveweight gain. The data on 3 pigs, from the treatments $\mathrm{A}, \mathrm{C}$ and $\mathrm{D}$ respectively, have not been included here as their liveweight gain deviated from the average for that particular treatment by more than twice the standard deviation. The growth results were also corrected to take account of differences in liveweight gain in the preexperimental period, and the unequal number of barrows and gilts. Fig. 1 shows the liveweight gain as a function of the lysine content, calculated on the basis of an EW of 1.03 .

Up to $70 \mathrm{~kg}$ the lysine content of both feeds had a significant effect on growth re-

Table 4. Liveweight gain (g/day) and feed conversion (calculated $\mathrm{EW} / \mathrm{kg}$ liveweight gain). ${ }^{1}$

\begin{tabular}{|c|c|c|c|c|c|c|c|}
\hline \multirow[t]{2}{*}{ feed } & \multirow{2}{*}{$\begin{array}{l}\text { calculated } \\
\text { lysine } \mathrm{g} / \mathrm{kg}\end{array}$} & \multicolumn{2}{|l|}{$30-70 \mathrm{~kg}$} & \multicolumn{2}{|l|}{$70-110 \mathrm{~kg}$} & \multicolumn{2}{|l|}{$30-110 \mathrm{~kg}$} \\
\hline & & $\begin{array}{l}\text { liveweight } \\
\text { gain }\end{array}$ & $\begin{array}{l}\text { feed } \\
\text { conversion }\end{array}$ & $\begin{array}{l}\text { liveweight } \\
\text { gain }\end{array}$ & $\begin{array}{l}\text { feed } \\
\text { conversion }\end{array}$ & $\begin{array}{l}\text { liveweight } \\
\text { gain }\end{array}$ & $\begin{array}{l}\text { feed } \\
\text { conversion }\end{array}$ \\
\hline A & 6.9 & 840 & 2.73 & 1028 & 3.24 & 922 & 2.99 \\
\hline B & 7.5 & 873 & 2.59 & 1016 & 3.22 & 937 & 2.90 \\
\hline $\mathrm{C}$ & 8.1 & 882 & 2.56 & 982 & 3.35 & 926 & 2.96 \\
\hline D & 6.9 & 814 & 2.83 & 952 & 3.42 & 875 & 3.11 \\
\hline $\mathrm{E}$ & 7.5 & 838 & 2.75 & 977 & 3.39 & 898 & 3.07 \\
\hline $\mathrm{F}$ & 8.1 & 872 & 2.61 & 982 & 3.34 & 922 & 2.97 \\
\hline \multicolumn{8}{|c|}{ Interaction lysine } \\
\hline \multicolumn{2}{|c|}{$A+B+C$} & 865 & 2.63 & 1009 & 3.27 & 929 & 2.95 \\
\hline \multicolumn{2}{|c|}{$D+E+F$} & 841 & 2.73 & 970 & 3.38 & 899 & 3.05 \\
\hline \multicolumn{2}{|c|}{ Difference } & * & $* *$ & $* *$ & * & $* *$ & $* *$ \\
\hline$A+D$ & 6.9 & 827 & 2.78 & 990 & 3.33 & 899 & 3.05 \\
\hline$B+E$ & 7.5 & 855 & 2.67 & 996 & 3.30 & 918 & 2.98 \\
\hline$C+F$ & 8.1 & 877 & 2.58 & 982 & 3.34 & 924 & 2.96 \\
\hline \multicolumn{2}{|c|}{ Linear effect } & $* *$ & $* *$ & - & - & $* *$ & $* *$ \\
\hline
\end{tabular}

${ }^{1} \mathrm{~A}, \mathrm{~B}$ and $\mathrm{C}$ are with easily digestible protein, $\mathrm{D}, \mathrm{E}$ and $\mathrm{F}$ with poorly digestible protein.

${ }^{*} \mathrm{P}<0.05$; ${ }^{* *} \mathrm{P}<0.01$.

${ }^{1} \mathrm{EW}=$ net energy content $(\mathrm{kJ} / \mathrm{kg})$ according to Rostock formula, divided by $8800 \mathrm{~kJ} / \mathrm{kg}$.

Neth. J. agric. Sci. 32 (1984) 
sults. However the feed containing easily digestible protein registered only a slight improvement in liveweight gain under influence of the increase of the lysine level, from 7.5 to $8.1 \mathrm{~g} / \mathrm{kg}$. After the pigs had reached $70 \mathrm{~kg}$ liveweight there was a difference between the feeds with poorly and easily digestible protein. On the feeds with poorly digestible protein the liveweight gain of the pigs was better as the lysine content of the feeds increased.

On the easily digestible protein, however, liveweight gain in pigs weighing over $70 \mathrm{~kg}$ decreased as lysine content increased. Up to $70 \mathrm{~kg}$ liveweight the pigs on the easily digestible protein received insufficient lysine and protein at the lowest lysine level for optimal protein deposition, but over $70 \mathrm{~kg}$ liveweight the protein supply is so high that these pigs showed some compensatory growth. The pigs at the highest lysine level apparently received sufficient lysine for optimal growth up till $70 \mathrm{~kg}$, so that they showed no compensatory growth at the $70-100 \mathrm{~kg}$ stage. To a slightly lesser extent the same is true of the second lysine level.

Over the entire growth range the feed with easily digestible protein showed only slight differences in liveweight gain under the influence of the lysine level. However, this does not hold true for the rations containing poorly digestible protein, which registered a significant improvement in liveweight gain as the lysine content of the feed rose.

\section{Digestibility trial}

The digestibility coefficients of the crude protein from feeds A, C, D and F are shown in Table 5. On the basis of the digestibility coefficients of the other nutrients, the

Table 5. Digestibility coefficients of crude protein (average of 6 determinations per feed).

\begin{tabular}{llll}
\hline Feed & $\begin{array}{l}\text { Calculated lysine } \\
\text { content }(\mathrm{g} / \mathrm{kg} \text { feed })\end{array}$ & $\begin{array}{l}\text { Digestibility } \\
\text { coefficient } \\
\left(\overline{\mathrm{x}} \pm \sigma_{\mathrm{x}}\right)\end{array}$ & $\begin{array}{l}\text { Digestibility coefficient } \\
\text { based on CVB table }\end{array}$ \\
$\mathrm{A}$ & 7.3 & $78.4 \pm 1.5$ & 85.9 \\
$\mathrm{C}$ & 8.5 & $77.6 \pm 2.0$ & 87.4 \\
$\mathrm{D}$ & 6.9 & $70.9 \pm 2.9$ & 82.6 \\
$\mathrm{~F}$ & 8.1 & $71.7 \pm 2.6$ & 84.4 \\
\hline
\end{tabular}

Table 6. Digestibility coefficients of lysine (two determinations per experimental feed).

\begin{tabular}{llll}
\hline Feed & $\begin{array}{l}\text { Calculated lysine } \\
\text { content }(\mathrm{g} / \mathrm{kg} \text { feed })\end{array}$ & $\begin{array}{l}\text { Digestibility } \\
\text { coefficient }\end{array}$ & $\begin{array}{l}\text { Digestibility coefficient } \\
\text { based on CVB table }\end{array}$ \\
A & 7.3 & $76.8-74.6$ & 89.0 \\
C & 8.5 & $77.4-76.4$ & 90.0 \\
D & 6.9 & $68.8-69.7$ & 84.2 \\
F & 8.1 & $73.1-69.6$ & 85.7 \\
\hline
\end{tabular}


Table 7. Requirement for gross and digestible lysine (in feeds with $\mathrm{EW}=1.03$ ).

\begin{tabular}{lcl}
\hline & $\begin{array}{l}\text { Feed with easily } \\
\text { digestible protein }\end{array}$ & $\begin{array}{l}\text { Feed with poorly } \\
\text { digestible protein }\end{array}$ \\
Requirement for gross lysine $(\mathrm{g} / \mathrm{kg})$ & $7.0-7.5$ & $\geqslant 7.9$ \\
Digestibility coefficient of the lysine & 76.3 & 70.3 \\
Requirement for digestible lysine $(\mathrm{g} / \mathrm{kg})$ & $5.3-5.7$ & $\geqslant 5.6$ \\
\hline
\end{tabular}

EW of the feeds was calculated according to the Rostock formula. For feeds A, C, $\mathrm{D}$ and $\mathrm{F}$ this was $1.056,1.038,0.993$ and 0.980 respectively, after correction for the added Celite. The calculated levels were higher: 1.084, 1.079, 1.031 and 1.027 respectively.

Table 6 shows the digestibility coefficients of lysine as they were determined and calculated on the basis of the digestibility coefficient of the crude protein and the gross lysine content of the feedstuffs, according to the CVB table.

On an average the digestibility of lysine from the easily digestible protein was $76.3 \pm 1.2$ and from the poorly digestible protein $70.3 \pm 1.9$ (Table 7).

\section{Discussion}

On account of the determined EW values of the feeds one can conclude that there were no differences in energy supply between the treatments. Thus all the differences in liveweight gain must be ascribed to differences in protein supply. (The somewhat lower EW values determined in the digestibility trial as compared to the calculated values can possibly be accounted for by the age of the pigs in the digestibility trial.)

The feed with poorly digestible protein showed over the entire growth range an improvement in liveweight gain each time the lysine level was increased (Fig. 1). Thus the lysine requirement is at least equal to the highest level tested in this trial; the results of analyses show this to be $7.9 \mathrm{~g} / \mathrm{kg}$. In the case of the feed with easily digestible protein the lysine level had almost no effect on growth rate. The lysine requirement, calculated on the basis of an EW of 1.03, was somewhere between 7.0 $\mathrm{g} / \mathrm{kg}$ and $7.5 \mathrm{~g} / \mathrm{kg}$. In practical terms the difference in lysine requirement which we discovered between feeds with easily digestible protein and those with poorly digestible protein means that in the feed with easily digestible protein circa $3 \%$ less soya has to be included than might be expected on the basis of the lysine requirement, as determined for the feed with poorly digestible protein. In a previous (unpublished) trial carried out at our institute with the same type of pigs, no significant difference in growth results was found between 7.6 and $8.5 \mathrm{~g}$ lysine per kg. And in a trial carried out in 1973 there was no difference in liveweight gain or feed conversion between feeds with 7.6 and $8.3 \mathrm{~g}$ lysine per $\mathrm{kg}$. In both trials, rations were used with a high level of soya bean oil meal. Thus the protein was easily digestible. This explains the agreement with the results on the feed with easily digestible protein in this trial. 


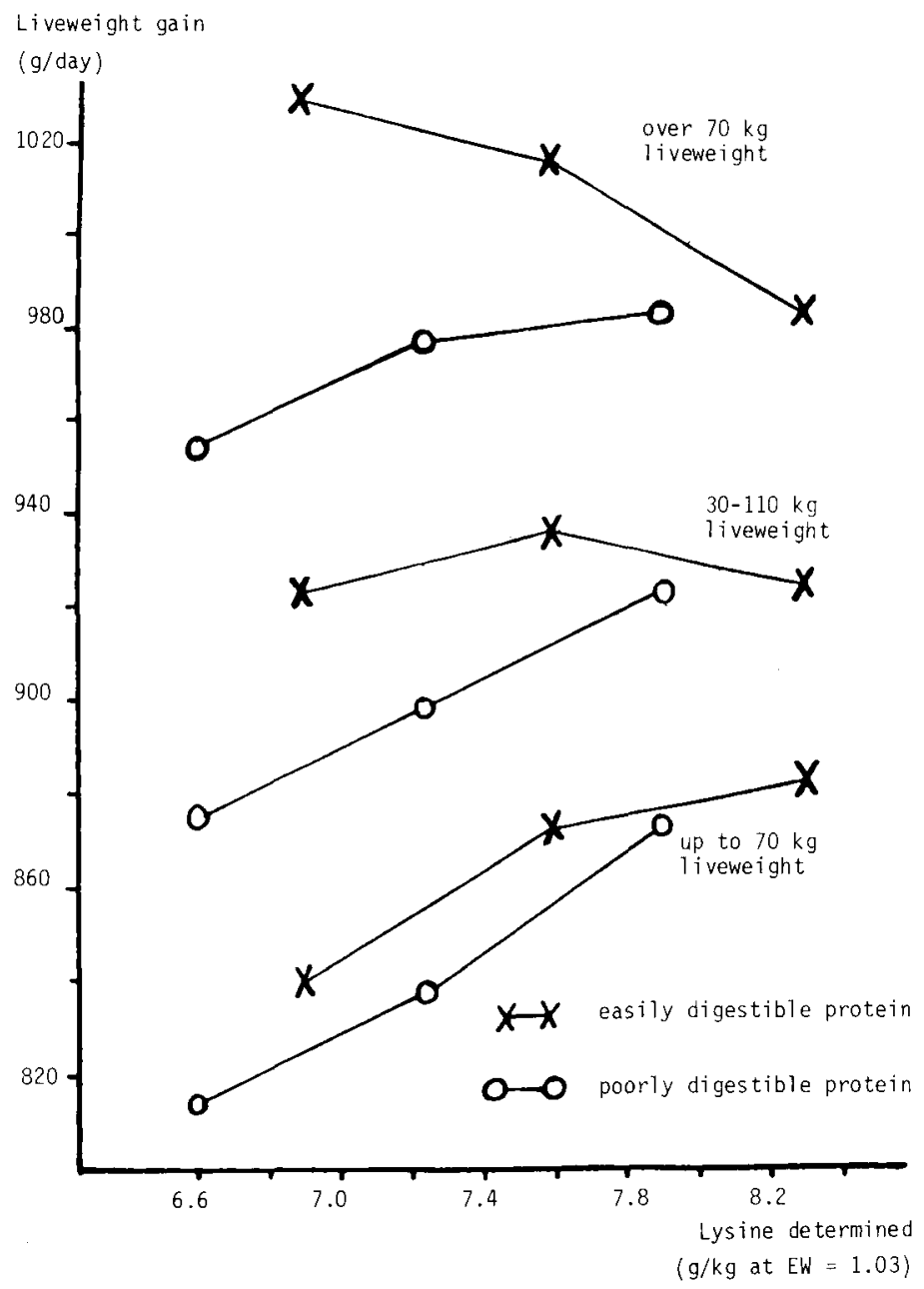

Fig. 1. Relationship between gross lysine content of feed and liveweight gain

The fact that the lysine requirement is apparently dependent on the digestibility of the crude protein proves the inadvisability of using gross amino acid requirements in pig feeding.

With the digestibility coefficients established for lysine (Table 6) it is possible to calculate the digestible lysine requirement for each of the two feeds (Table 7). In spite of the fact that the composition of the two feeds was quite different, the requirement for digestible lysine was found to be more or less the same for both feeds.

In our trial there proved to be quite close agreement between the apparent faecal digestibility of the crude protein and that of the lysine (Tables 5 and 6). This is in 
contrast with the results of many other experiments which showed that the digestibility of the individual amino acids can deviate substantially from that of the crude protein. Van Weerden et al. (1980) found this to be true for, among other amino acids, lysine and threonine in feeds containing two different levels of crude fibre. The digestibility of lysine is nearly always the lowest of all the amino acids and lower than that of the total protein in diets with a low protein digestibility (Lenis, 1980). Moreover, the composition of the ration was found to affect the difference between the digestibility of lysine and that of the crude protein (Slump et al., 1977; Lenis, 1980). The fact that we found fairly close agreement between the digestibility of crude protein and lysine can probably be attributed to the choice of feeding stuffs used.

The above data clearly show that it is advisable to formulate pig feeds on the basis of digestible amino acids. However up to now this is not possible since data about the digestibility coefficients of the individual amino acids of the feeding stuffs are scarce.

Moreover, digestibility is usually determined at the end of the digestive tract by analysing the faeces (apparent digestibility). For the animal, however, it is important to know what portion of the amino acids has been absorbed at the end of the ileum.

In the colon proteins and products of hydrolysis are further broken down by bacteria (e.g. Zebrowska et al., 1977). Synthesis of amino acids is also possible in the colon, as shown by the literature study carried out by Lenis (1980). The degree to which amino acids are converted in the hind-gut depends on the energy available to the flora, and is higher when the ration contains a high proportion of poorly digestible carbohydrates (Low, 1982). Lenis (1980) concluded however that in general for the first-limiting amino acid lysine, and also for the sum of methionine and cystine, the apparent digestibility as determined at the end of the entire gastro-intestinal tract is a fairly good indication of the availability of these essential amino acids. This applies to easily digestible as wel as poorly digestible rations.

The digestibility coefficients we found for crude protein deviated sharply from the figures calculated according to data from the CVB table (Table 5). We also found the differences in digestibility coefficients between feeds with easily digestible and poorly digestible protein sources to be larger than calculated. The protein digestibility coefficients for feedstuffs given in the CVB table are based on trials with older pigs than those we used, and for younger pigs generally lower protein digestibility coefficients are found. However the differences are so great that we do not believe this can be the sole explanation. The high feed level in our trial may also have been a factor. At a higher feed level the digesta passes more rapidly through the intestinal tract, and this could mean that the enzymes were not able to exert their full influence.

From experiments of B. J. Wieman, A. J. Jongbloed \& Y. van der Honing (pers. commun.) (1983) it can also be deducted that both age of the pig and feeding level may influence digestibility. 


\section{References}

Lenis, N. P., 1980. De aminozuurverteerbaarheid bij het varken en de rol van de bacterieflora in de dikke darm en de bijdrage van het endogene eiwit. Instituut voor Veevoedingsonderzoek IVVO, Lelystad, Rapport No 133.

Low, A. G., 1982. Digestibility and availability of amino acids from feedstuffs for pigs. Livestock Production Science 9: 511-520.

Slump, P., L. van Beek, W. M. M. A. Janssen, K. Terpstra, N. P. Lenis \& B. Smits, 1977. A comparative study with pigs, poultry and rats of the amino acid digestibility of diets containing crude protein with diverging digestibilities. Proceedings 2nd International Symposium on Protein Metabolism and Nutrition (May 1977). EAAP Publ. 22. Pudoc, Wageningen, pp. 70-72.

Weerden, E. J. van, P. Slump \& J. Huisman, 1980. Amino acid digestion in different parts of the intestinal tract of pigs. Proceedings 3rd International Symposium on Protein Metabolism and Nutrition (Braunschweig). EAAP Publ. 27, Vol. 1: 207-214.

Zebrowska, T. \& S. Buraczewski, 1977. Digestibility of amino acids along the gut of pigs. Proceedings 2nd International Symposium on Protein Metabolism and Nutrition (May 1977). EAAP Publ. 22. Pudoc, Wageningen, pp. 82-85. 